ISSN: 1858-4837; E-ISSN: 2598-019X

Volume 17, Nomor 1 (2022),

https://jurnal.uns.ac.id/region

DOI: 10.20961/region.v1711.33390

\title{
Kebertahanan fisik Kampung Beting sebagai kawasan permukiman waterfront heritage
}

\author{
The physical resiliency of Kampung Beting as the waterfront heritage \\ settlement
}

\author{
M J Yastri ${ }^{1}$, W Astuti ${ }^{1}$, dan R A Putri ${ }^{1}$ \\ ${ }^{1}$ Program Studi Perencanaan Wilayah dan Kota, Fakultas Teknik, Universitas Sebelas \\ Maret
}

Corresponding author's email: mariskajessica@student.uns.ac.id

\begin{abstract}
Abstrak. Semakin berkembangnya kawasan komersial di daratan, maka semakin berkembang pula permasalahan di bagian kota lainnya. Seperti halnya permukiman Kampung Beting di tepian Sungai Kapuas, Kota Pontianak. Angka kemiskinan yang tinggi serta tingkat pendidikan penduduknya yang sangat rendah membentuk karakter kampung yang negatif bagi sebagian besar masyarakat di Kota Pontianak. Kampung Beting juga tidak dapat terlepas dari nilai sejarah yang dimilikinya sebagai cikal bakal permukiman pertama, sejarah tersebut membentuk karakter kampung yang sarat akan budaya Melayu Pontianak baik dari maupun non fisiknya yaitu budaya perairan. Permasalahan tentang menurunnya kualitas kampung tepian air atau sungai, telah diatasi dengan program kampung tepi air oleh pemerintah dan masyarakat. Program tersebut bertujuan untuk memperbaiki kualitas fisik dan kualitas hidup masyarakat di dalamnya, yang nantinya akan menghasilkan kampung wisata. Kebertahanan adalah dimana kawasan tersebut dapat beradaptasi dalam mempertahankan karakter kawasannya. Oleh karena itu, tujuan penelitian ini adalah untuk menganalisis kebertahanan kawasan dengan karakter kampung waterfront heritage yang ideal melalui adaptasi fisiknya. Penelitian ini menggunakan metode analisis deskriptif kualitatif dengan model analisis data Miles dan Huberman, didapat hasil bahwa kebertahanan Kampung Beting melalui adaptasi fisik memiliki nilai kebertahanan yang cukup. Karakter fisik kampung menunjukkan bahwa kawasan tersebut memiliki elemen-elemen fisik yang dapat menunjukkan karakter atau identitas waterfront heritage yang ideal dari segi ketersediaan dan kesesuaian fungsinya. Yakni elemen jalur jalan, sarana dan prasarana transportasi air, promenade, dan aset historis yang mengalami konservasi. Sementara elemen lainnya yakni ruang terbuka dan bangunan
\end{abstract}


tepi air belum mampu menunjang karakter atau identitas kawasan sebagai permukiman waterfront heritage yang ideal.

Kata Kunci: Karakter Waterfront Heritage; Kebertahanan Fisik; Kebertahanan Kampung; Ketersediaan dan Kesesuaian Fisik

\begin{abstract}
As the development of commercial areas on land, causes the more problems on other parts of city. Like on Kampung Beting settlements on the banks of the Kapuas River, Pontianak City. High poverty rate and low education level of population form a negative character for most people in Pontianak City. Kampung Beting also known as the forerunner of the first settlement, that history forms the character of village which is full of Pontianak Malay culture both from and non-physically, namely aquatic culture. Problems regarding the declining of waterfront villages quality or rivers have been overcome by waterfront village program by government and community. The program aims to improve physical and life quality of the people in it, which will later produce tourist villages. Resiliency is where the region can adapt in maintaining its regional character. Therefore, the purpose of this study is to analyze the sustainability of the region with the village character of waterfront heritage that is ideal through its physical adaptation. This study used a qualitative descriptive analysis method with Miles and Huberman data analysis models. The results obtained that the survival of Kampung Beting through physical adaptation has sufficient survival value. Physical character of the village shows that the area has physical elements that can show the character or identity of a heritage waterfront that is ideal in terms of availability and suitability of its functions. Those elements are road, water transportation facilities and infrastructure, promenades and historical assets that have experienced conservation. While other elements (open space and waterfront buildings) have not been able to support the character or identity of the region as an ideal heritage waterfront settlement.
\end{abstract}

Keywords: Physical Availability and Suitability; Resiliency; Village Resilience; Waterfront Heritage Character

\title{
1. Pendahuluan
}

Perkembangan Kota Pontianak yang terfokus kepada pembangunan di daratan, mengakibatkan penurunan kualitas di bagian lain dari perkotaan tersebut. Kota Pontianak berkembang sebagai kota dengan sungai terpanjang di Indonesia, yaitu Sungai Kapuas. Cikal bakal permukiman pertama di Kota Pontianak pun tumbuh di tepian sungai, yang dikenal sebagai Kampung Beting. Nilai sejarah kampung yang sarat akan makna budaya air ditunjukkan dengan ciri khas fisik bangunan dan arsitektur tradisional atau rumah panggung, selain itu dari segi non fisiknya dengan aktivitas permukiman yang bergantung terhadap keberadaan sungai salah satunya transportasi sungai dan pemanfaatan air sungai itu sendiri [1]. Kondisi kawasan penelitian yang kumuh dan memiliki stigma negatif akan tetapi di sisi lainnya memiliki potensi nilai sejarah dan wisata air kemudian ditangani oleh pemerintah melalui program perbaikan kampung tepi air. Berbagai pembangunan fisik dan non-fisik 
dilakukan untuk meningkatkan kualitas lingkungan dan kualitas hidup masyarakat. Program tersebut mengarahkan kampung sebagai kampung wisata tepi air [2].

Kebertahanan adalah kemampuan sistem untuk mempertahankan identitasnya [3]. Identitas atau karakter yang dimaksud adalah permukiman Kampung Beting yang memiliki jati diri sebagai kawasan budaya, kawasan wisata, dan kawasan tepian sungai. Untuk lebih jelasnya, karakter yang dimiliki Kampung Beting adalah permukiman waterfront heritage. Dalam menilai kebertahanan karakter Kampung Beting tersebut, dilakukan melalui analisis kemampuan adaptasi dari keseluruhan aspek fisik pembentuk permukiman waterfront heritage. Kebertahanan permukiman dapat diartikan sebagai kemampuan dari keseluruhan elemen pembentuk permukiman untuk mengadaptasi perubahan, baik perubahan sosial, politik serta lingkungan dengan melakukan adaptasi [4]. Pendekatan penilaian karakter kawasan melalui adaptasi, terbentuk dari beberapa elemen fisik yaitu ruang terbuka (open space), jalur jalan sebagai penghubung, sarana dan prasarana transportasi air, promenade, rumah dan bangunan tepi air, dan aset historis yang dikonservasi. Kinerja sumber daya atau kinerja elemen pembentuk karakter kawasan dapat dinilai dari ketersediaan dan kualitasnya dalam mencapai peran dan fungsinya [5]. Ketersediaan dilihat dari ada atau tidaknya tiap-tiap elemen tersebut. Kualitas peran dan fungsi dilihat bagaimana peran elemen yang ada dapat berjalan sesuai dengan fungsinya. Seiring berkembangnya aktivitas pembangunan di kawasan penelitian, berkembang pula perubahan-perubahan kondisi karakter permukiman waterfront heritage. Untuk mencapai kebertahanan karakternya, maka terdapat elemen pembentuk yang harus terpenuhi dari segi kinerjanya.

Beberapa penelitian mengenai ketahanan permukiman dan lokus studi Kampung Beting telah ada, akan tetapi peneliti belum menemukan penelitian yang mengkaji tentang ketahanan permukiman dengan karakteristik waterfront dan memiliki nilai historis. Sari [6] dan Khaliesh, et al [7] menemukenali karakter permukiman ditinjau dari perkembangan konsep arsitektur bangunannya, namun tidak mengkaji tentang kebertahanannya. Puastika dan Yuliastuti [4] meneliti tentang kebertahanan permukiman, namun ditinjau dari kemampuannya mengatasi bencana rob air laut, tidak mengkaji kebertahanan secara historis. Dalam hal ini, kebaruan yang diangkat pada penelitian ini adalah bagaimana kebertahanan karakter Kampung Beting dilihat dari kinerja fisik elemen pembentuk waterfront heritage yang ideal.

\section{Metode}

Ruang lingkup wilayah penelitian ini terletak di Kampung Beting yang berada pada dua kawasan fungsional yaitu sebagian Kelurahan Dalam Bugis dan sebagian Kelurahan Tambelan Sampit dengan luas 30,7 ha.

\subsection{Pendekatan dan jenis penelitian}

Penelitian ini menggunakan pendekatan deduktif, yaitu menggunakan teori umum kemudian dianalisis secara khusus melalui fenomena studi kasus. Fenomena studi kasus dalam penelitian ini terkait dengan kebertahanan Kampung Beting sebagai kawasan permukiman waterfront heritage. Penelitian ini menggunakan jenis penelitian deskriptif kualitatif. Kedalaman penelitian ini ada pada bentuk penelitian yang eksploratif terhadap obyek penelitian [8]. 
Deskripsi pada penelitian ini adalah deskripsi kebertahanan karakter permukiman waterfront heritage dilihat dari kinerja fisiknya pada Kampung Beting.

\subsection{Teknik sampling}

Penentuan sampling dalam penelitian ini menggunakan metode non probability sampling dengan teknik purposive sampling. Penentuan narasumber menggunakan teknik snowball sampling, dan dihasilkan 4 narasumber utama (key person) dari beberapa latar belakang (pemerintah, NGO, dan tokoh masyarakat) yang dianggap mumpuni dalam memahami perubahan-perubahan yang berpengaruh terhadap adaptasi fisik karakter Kampung Beting.

\subsection{Teknik pengumpulan data dan analisis data}

Penelitian ini menggunakan 4 (empat) teknik pengumpulan data yaitu wawancara terbuka, observasi non partisipan, studi dokumen, dan catatan lapangan. Sedangkan teknik analisis data yang digunakan adalah analisis data kualitatif model Miles dan Huberman [9]. Dalam penelitian kualitatif, rangkaian kegiatan analisis dilakukan sebelum dan setelah studi lapangan dilakukan (lihat Tabel 1).

Tabel 1. Tahapan teknik analisis data model Miles dan Huberman dalam penelitian kebertahanan Kampung Beting sebagai permukiman waterfront heritage.

\begin{tabular}{|c|c|c|}
\hline Waktu Kegiatan & $\begin{array}{l}\text { Tahapan } \\
\text { Kegiatan }\end{array}$ & Proses Analisis \\
\hline $\begin{array}{l}\text { Sebelum } \\
\text { lapangan }\end{array}$ & $\begin{array}{l}\text { Penentuan fokus } \\
\text { penelitian }\end{array}$ & $\begin{array}{l}\text { - Studi pendahuluan terkait karakter } \\
\text { pembentuk Kampung Beting } \\
\text { - Penentuan narasumber utama terkait } \\
\text { informasi impresi karakter Kampung } \\
\text { Beting }\end{array}$ \\
\hline \multirow{6}{*}{$\begin{array}{l}\text { Analisis selama } \\
\text { dan setelah di } \\
\text { lapangan }\end{array}$} & Reduksi data & $\begin{array}{l}\text { - Pengumpulan dan pemilahan studi } \\
\text { dokumen }\end{array}$ \\
\hline & & - Penyusunan catatan lapangan \\
\hline & & $\begin{array}{l}\text { - Penyusunan transkrip wawancara } \\
\text { dengan pengkodean }\end{array}$ \\
\hline & $\begin{array}{l}\text { Matriks data dan } \\
\text { kesimpulan }\end{array}$ & $\begin{array}{l}\text { - Display data dengan persandingan hasil } \\
\text { tiap pengumpulan data dengan } \\
\text { menganalisis pola kesamaan hasil data }\end{array}$ \\
\hline & & $\begin{array}{l}\text { - Hasil data akan dipaparkan secara } \\
\text { deskriptif berdasarkan teori kinerja } \\
\text { (ketersediaan dan kesesuaian fungsi) tiap } \\
\text { elemen pembentuk karakter Kampung } \\
\text { Beting }\end{array}$ \\
\hline & Verifikasi & $\begin{array}{l}\text { - Triangulasi data dengan teknik } \\
\text { triangulasi sumber }\end{array}$ \\
\hline
\end{tabular}


Output analisis kebertahanan karakter Kampung Beting kemudian dideskripsikan pada masing-masing variabel dan sub variabel dengan menggunakan analisis deskriptif kualitatif. Hasil tiap variabel dan sub variabel tersebut kemudian disintesis secara berkelompok untuk memilah sub variabel mana yang memiliki nilai kinerja baik dan tidak baik sesuai dengan hasil pendeskripsian. Penilaian penentuan skoring pengukuran per variabel dan sub variabel menggunakan skala Guttman, dengan kriteria objektif cukup jika skor $\geq 50 \%$ dan rendah jika skor $<50 \%$.

Penentuan kesimpulan hasil kebertahanan pada tiap variabel/ komponen kinerja fisik tersebut dilakukan dengan mensintesis hasil penilaian sub variabel. Sintesis tersebut menggambarkan persentase nilai objektif berdasarkan hasil deskripsi. Berdasarkan hasil tersebut nantinya akan diketahui kinerja variabel keseluruhan.

\section{Hasil penelitian dan pembahasan}

Berdasarkan analisis data kualitatif model Miles dan Huberman dengan hasil deskriptif didapatkan hasil bahwa kebertahanan karakter Kampung Beting dilihat dari segi fisiknya berada dalam kondisi kebertahanan cukup. Kebertahanan fisik kawasan penelitian ada pada aspek kinerja ruang terbuka, kinerja jalur, kinerja transportasi air, kinerja promenade, kinerja rumah dan bangunan tepi air, serta kinerja aset historis kawasan yang dikonservasi. Dari 6 (enam) variabel yang ada, didapatkan bahwa terdapat 4 (empat) variabel yang mencukupi nilai kebertahanan.

\subsection{Kinerja ruang terbuka (open space)}

Sebagai kawasan tepian sungai, Kampung Beting memiliki ruang terbuka yang cukup mudah ditemukan. Ruang terbuka yang ada di kawasan penelitian merupakan ruang publik yang bersifat rekreatif baik untuk penduduk di dalamnya maupun para pengunjung. Komponen pendukung ruang terbuka ada 9, yaitu: dermaga, area memancing, area permandian, area bermain anak-anak, lapangan terbuka hijau, toilet permanen, lapangan olahraga, area berjualan, dan lahan parkir. Kesemua komponen tersebut dilihat ketersediaan dan kesesuaian fungsinya berdasarkan hasil catatan dan observasi lapangan. Didapatkan bahwa 2 dari 9 komponen yang mencukupi nilai adaptif (kinerja) ruang terbuka hijau yaitu dermaga dan lapangan terbuka hijau. Hal tersebut menunjukkan bahwa elemen pendukung kinerja ruang terbuka belum dapat mencukupi kriteria ideal ruang terbuka sebagaimana mestinya.

Kinerja dermaga dan lapangan terbuka hijau, masing-masing memiliki perannya dalam mendukung adaptasi fisik ruang terbuka hijau di kawasan waterfront. Adanya dermaga menunjukkan bahwa fungsi aktivitas perairan sebagai ruang terbuka masih eksis. Kesesuaian fungsi dermaga di kawasan adalah sebagai tempat bersandar kapal/perahu yang sekaligus berfungsi sebagai jalan di atas air untuk menghubungkan daratan dengan kapal atau perahu. Meskipun ada beberapa dermaga yang tidak sesuai fungsinya akibat faktor lingkungan dan geografis yaitu pendangkalan sungai. Dermaga juga dapat berfungsi sebagai area kumpul atau tempat duduk masyarakat dan pengunjung sekitar. Ketersediaan dermaga yang ada di kawasan penelitian berjumlah 10 (sepuluh). Ditemukan 3 (tiga) dermaga dengan kualitas yang kurang baik. Terutama dari fungsinya, dermaga sebagai tempat untuk parkir kapal dan 
menaikkan penumpang kapal, tidak dapat beroperasi dengan baik karena adanya faktor lingkungan yaitu pendangkalan sungai. Sehingga dermaga tersebut memberikan kesan tidak terpelihara dan kumuh.

Lapangan terbuka hijau di kawasan adalah halaman Masjid Jami' dengan luas lahan kurang lebih $278 \mathrm{~m}^{2}$. Letak lapangan merupakan zona paling depan atau zona yang langsung berbatasan dengan daerah perairan utama. Dari segi fungsinya, halaman Masjid Jami' menjadi tempat bertemunya aktivitas-aktivitas ruang terbuka di Kampung Beting baik dari masyarakat kampung maupun wisatawan yang berkunjung. Apalagi ketika sore hingga malam hari, banyak aktivitas yang terjadi di ruang tersebut mengingat masyarakat Kampung Beting tidak memiliki halaman depan rumah sehingga anak-anak tidak leluasa bermain. Dari segi kenyamanan, ketika sore hari angin bertiup sepoi-sepoi di halaman ini karena tidak adanya penghalang secara langsung antara sungai dengan halaman.

Sebagai komponen rekreatif, tidak tersedianya sarana penunjang tentunya berdampak terhadap fungsi ruang terbuka sebagai wadah yang dapat menampung kegiatan maupun aktivitas masyarakat yang berhubungan dengan edukasi, rekreasi, dan sosial masyarakat. Tidak tersedianya area memancing, area berenang, area bermain anak-anak, dan lapangan olahraga berdampak terhadap penurunan kinerja ruang terbuka sebagai wadah aktivitas edukasi dan rekreasi. Selain itu juga menimbulkan kesan bagi pengunjung bahwa pemilihan alternatif rekreasi yang tidak menarik. Sementara tidak tersedianya toilet publik, area berjualan, dan lahan parkir yang ideal berdampak terhadap penurunan kinerja ruang terbuka sebagai wadah kegiatan sosial masyarakat.

\subsection{Kinerja jalur sebagai akses dan penghubung}

Jalur atau jaringan pergerakan di Kampung Beting berasal dari terbangunnya rumah-rumah panggung yang semula merupakan rumah lanting (rumah apung). Kondisi fisik lingkungan sungai yang semakin dangkal mengakibatkan rumah-rumah masyarakat berubah menjadi rumah panggung yang lebih kokoh dan permanen. Kumpulan rumah-rumah panggung di Kampung Beting mengikuti jalur parit atau sungai kecil membentuk kanal-kanal yang berfungsi sebagai jalur lalu lintas perahu. Perubahan tipe bangunan rumah juga mempengaruhi munculnya jembatan-jembatan penghubung antar rumah, penduduk lokal mengenalnya dengan nama gertak. Gertak di kawasan juga dilengkapi dengan tempat duduk yang biasa disebut 'bangku kumpol', lampu jalan, dan tempat sampah.

Dari segi fungsi ideal, gertak di kawasan harus memenuhi indikator antara lain material aspal atau perkerasan, area tempat duduk ideal, serta tersedianya lampu jalan dan tempat sampah. Konstruksi jaringan jalan di kawasan penelitian terdiri atas 2 (dua) jenis yaitu konstruksi beton (perkerasan) dan konstruksi kayu. Hasil persentase konstruksi jalan atau jalur didominasi oleh jalan dengan material beton (perkerasan) yaitu sebesar $88,3 \%$. Area tempat duduk atau 'bangku kumpol' secara keseluruhan dalam kondisi baik. Hanya terdapat 2 (dua) area tempat duduk yang menggunakan material semen. Selain itu, keseluruhan area tempat duduk yang ada di kawasan penelitian juga memiliki sandaran bangku. Kemudian dilihat dari interval 
lokasinya, area tempat duduk tersebar di setiap titik pusat permukiman penduduk di kawasan penelitian.

Dapat disimpulkan bahwa kinerja jalur di kawasan penelitian memiliki kinerja yang tinggi. Dari konstruksi jalan yaitu minimnya jalur yang rusak, dari ketersediaan area tempat duduk yang mudah ditemukan dan tersedianya lampu jalan berdampak terhadap kemudahan akses baik daratan maupun akses menuju perairan (terminal sampan dan dermaga).

\subsection{Kinerja transportasi air}

Sebagai kawasan waterfront, transportasi sungai juga berperan penting dalam budaya penduduk sebagai karakter Kampung Beting. Transportasi air dibagi menjadi 2 (dua) yaitu sarana transportasi air dan prasarana transportasi air. Sarana transportasi yang berkaitan dengan penelitian ini adalah kendaraan air atau sungai sebagai alat berpindahnya manusia dan barang. Jenis transportasi air yang ada di kawasan penelitian cukup beragam, akan tetapi dilihat dari ukurannya, sebagian besar kendaraan sungai yang ada di kawasan penelitian berukuran kecil. Transportasi air yang ada di kawasan penelitian antara lain sampan dayung, speedboat, kano, kafe kapal, dan warung apung. Jumlah alat transportasi air yang ada yaitu 159 unit dengan sistem kepemilikan pribadi. Dari segi fungsinya, pemanfaatan transportasi sungai di Kampung Beting diutamakan untuk wisata. Sementara untuk pemanfaatan dari penduduk asli, kendaraan air kurang mendapat eksistensinya karena hanya digunakan untuk rute terbatas sehingga berdampak terhadap pemilihan moda ke transportasi daratan bagi penduduk sekitar. Kendaraan air juga dimanfaatkan secara pribadi untuk alat perpindahan dalam mencari ikan.

Prasarana transportasi air yang dimaksud adalah trayek angkutan sungai dan pelabuhan. Trayek angkutan sungai di kawasan ada dua jenis yaitu trayek penyeberangan orang dan trayek wisata sungai. Sementara pelabuhan atau terminal sampan ada 2 (dua) yang secara fisik terbentuk secara swadaya. Akan tetapi, dari segi fungsi terminal sampan tersebut tetap dapat digunakan untuk keperluan menurunkan dan menaikkan penumpang dan perpindahan antar moda sungai dengan darat. Trayek penyeberangan orang ditujukan untuk penyebrangan dengan jarak dekat (sisi sungai yang satu dengan sisi sungai di seberangnya). Trayek wisata ditujukan untuk wisatawan yang hendak berkeliling melihat pemandangan kota.

Jasa transportasi sungai di Kampung Beting sudah mulai ditinggalkan, dengan kata lain pengguna jasa sampan untuk berpindah dan berpergian mengalami penurunan. Hal ini terjadi karena peralihan dalam penggunaan transportasi sungai ke transportasi darat. Pembangunan jalan darat, jembatan, dan kebijakan transportasi darat lainnya, mengancam keberadaan sampan sebagai transportasi utama Kampung Beting dan Kota Pontianak. Meskipun hingga saat ini, kendaraan air masih digunakan sebagai sarana wisata air, namun hanya dirasakan musiman dan tidak memberikan keuntungan bagi seluruh masyarakat kampung. Jika hal tersebut dibiarkan, transportasi sungai semakin kehilangan kinerjanya. Secara fisik, kendaraan air mulai langka dan mulai ditinggalkan karena tidak menjamin ekonomi pemiliknya. Secara fungsi, semakin lama transportasi air hanya menjadi alternatif pendukung wisata tetapi tidak melekat sebagai alat perpindahan penduduk yang menetap di tepian sungai. Dampaknya 
adalah hal tersebut dapat mematikan karakter Kampung Beting sebagai permukiman tepian sungai. Tidak hanya dari karakter fisik tetapi juga budaya perairan yang melekat sebagai identitas kampung.

\subsection{Kinerja promenade}

Promenade merupakan perkerasan di kawasan tepian air atau sungai untuk berjalan-jalan atau berkendara (sepeda atau kendaraan tidak bermotor lainnya) sambil menikmati pemandangan perairan [10]. Di Kampung Beting terdapat promenade dengan lebar jalan 1,75 $\mathrm{m}$ dan panjang jalan kurang lebih $911 \mathrm{~m}$ dengan bentuk fisiknya memiliki konstruksi beton dan dikelilingi pagar besi. Dari fungsinya, promenade dibangun untuk memenuhi kebutuhan aktivitas pejalan kaki di ruang kota atau ruang waterfront. Konstruksi promenade yang baik dapat berpengaruh terhadap terciptanya lingkungan tepi sungai yang aman dan nyaman. Selain itu juga menyenangkan bagi pengguna untuk bersantai, berolahraga, dan menikmati pemandangan. Kualitas fisik promenade di kawasan penelitian memiliki struktur yang kokoh dan terbuat dari material beton sehingga menciptakan lingkungan promenade yang aman dan nyaman.

Dari segi fungsinya, promenade dilihat dari kesesuaian fungsi pengguna. Prinsip utama dalam perancangan promenade adalah lanskap lingkungan hijau untuk publik, sehingga pengguna promenade hanya diarahkan untuk pejalan kaki dan sepeda. Pemanfaatan promenade di kawasan penelitian sudah memenuhi kriteria dengan indikator pengguna jalan kaki dan bersepeda. Adanya bastimal steps atau tangga pemandian, juga bertujuan untuk mendukung kinerja promenade untuk memudahkan orang mengakses zona perairan. Selain itu, terdapat juga area hijau di sepanjang tepian promenade sepanjang 95,3m. Titik persebaran area pepohonan hanya terdistribusi di promenade bagian Kelurahan Tambelan Sampit. Sementara di area permukiman Kelurahan Dalam Bugis, tidak ditemukan adanya pepohonan. Dilihat dari persentase area pepohonan secara keseluruhan, promenade di kawasan penelitian memiliki area hijau sebesar 10,5\%. Jika dilihat dari interval jarak tiap pohon sudah cukup sesuai, akan tetapi titik persebaran pepohonan dari segi kuantitas masih sangat kurang terutama di bagian Kelurahan Dalam Bugis sehingga mempengaruhi tingkat kenyamanan pengguna. Sesuai dengan kriteria yang telah ditentukan, pemilihan warna pada permukaan promenade harus berwarna dengan nuansa natural, dengan tujuan untuk menghindari silau cahaya matahari ketika siang hari dan silau pantulan lampu jalan ketika malam hari.

Dari 5 (lima) elemen pendukung yang ada, terdapat 4 (empat) elemen yang memenuhi kriteria ideal sehingga dapat disimpulkan bahwa kinerja promenade di Kampung Beting memiliki nilai tinggi, artinya kinerja promenade dapat memenuhi komponen kebertahanan karakter Kampung Beting sebagai kawasan permukiman waterfront heritage sebagaimana yang dijelaskan dalam tujuan penelitian ini.

\subsection{Kinerja rumah dan bangunan tepi air}

Sebagai kawasan permukiman, Kampung Beting juga memiliki kriteria ideal yang sama. Seperti kelengkapan sarana dan prasarana pendukung dan prasarana permukiman yang layak. Ketersediaan bangunan dengan ciri khas tepian sungai merupakan salah satu kriteria kinerja 
bangunan dalam mempertahankan karakter kampung. Rumah yang berada di Kelurahan Dalam Bugis dan Tambelan Sampit, hampir keseluruhan merupakan rumah tiang dengan bentuk panggung. Rumah yang berada di kompleks keraton, hampir keseluruhan tidak memiliki bentuk rumah tiang karena letaknya di daratan atau lebih tepatnya di pinggir sungai. Jumlah bangunan yang ada di kawasan penelitian yaitu 505 bangunan [11]. Dari keseluruhan bangunan tersebut, terdapat 59 rumah yang tidak memiliki ciri bangunan tepi air. Bangunan rumah dengan pondasi batu kali atau beton dengan fasad modern terlihat pada bangunan tersebut. Bangunan tersebut bukan tidak mempertahankan bentuk bangunan tepi air, akan tetapi karena memang secara geografis sudah termasuk ke dalam tanah daratan. Dari segi kesesuaian fungsi bangunan, dilihat dari kualitas rumah tersebut diketahui bahwa secara keseluruhan bangunan rumah di kawasan penelitian sudah memiliki surat tanah, tergolong aman dari pasang sungai dan sudah dilengkapi dengan jaringan listrik dari PLN.

Permukiman kampung juga sudah terlayani sarana pendidikan dengan adanya SD, SMP, SMA, dan MA yang menjangkau kawasan. Tersedia pula sarana perdagangan yaitu toko/warung dan Pasar Kenanga sebagai pasar tradisional, sarana tersebut dapat memenuhi kebutuhan seharihari penduduk. Pelayanan sarana kesehatan juga menjangkau kawasan yaitu adanya posyandu dan Puskesmas Kampung Dalam.

Ketersediaan prasarana pendukung permukiman seperti jaringan air bersih, jaringan sanitasi dan jaringan persampahan masih sangat jauh dari kata layak. Pelayanan air bersih yang minim dari pemerintah, 40\% KK yang belum memiliki tangki septik, dan pelayanan sistem persampahan yang belum efektif berdampak terhadap kondisi permukiman yang semakin kumuh. Kondisi kumuh tersebut melahirkan stigma negatif karakter kampung, kontradiktif dengan tujuan penelitian yang ada. Potensi kampung sebagai kawasan wisata budaya terhambat oleh tidak terkontrolnya peletakan bangunan, kurang didukung oleh prasarana lingkungan, serta jaringan sanitasi dan persampahan yang buruk. Hal tersebut juga berdampak terhadap pencemaran lingkungan khususnya air sungai dibuktikan dengan sedimentasi yang tinggi di tepian sungai. Bau tidak sedap dari parit/kanal juga kadang timbul di kawasan. Fenomena di atas menimbulkan ketidaknyamanan bagi pengunjung atau wisatawan yang seharusnya hal tersebut tidak ditemukan di kawasan wisata yang ideal.

\subsection{Kinerja aset historis kawasan yang dikonservasi}

Sebagai kawasan dengan peruntukan kawasan budaya, kawasan penelitian memiliki beberapa aset cagar budaya yang harus dikonservasi. Didapatkan bahwa aset historis yang berada di kawasan penelitian antara lain yaitu Masjid Jami' Sultan Syarif Abdurrahman, Monumen Perjuangan, dan Keraton Kadriyah. Karakteristik bangunan historis yang ada di kawasan penelitian merupakan gambaran karakteristik budaya Kota Pontianak, dengan ciri khas budaya Melayu.

Dari 3 (tiga) bangunan historis, ditemukan 2 (dua) bangunan yang dikonservasi yaitu Masjid Jami' Sultan Syarif Abdurrahman dan Keraton Kadriyah. Revitalisasi Masjid Jami' dilakukan oleh pemerintah pusat bersama dengan Pemerintah Kota Pontianak sebagai bagian dari 
penanganan Kawasan Kampung Beting. Untuk saat ini, kondisi bangunan Keraton Kadriyah masih cukup layak, adapun kegiatan rehabilitasi yang dilakukan yaitu pengecatan bangunan.

Dari segi fungsi, keberadaan Masjid Jami' sebagai rumah ibadah tertua di Kota Pontianak juga menjadikan masjid ini sebagai tujuan wisata religi baik dari dalam kota hingga luar kota. Di halaman terdapat bangunan yang digunakan untuk tempat ibadah sementara masyarakat Kampung Beting. Selain terdapat bangunan sementara, halaman masjid juga difungsikan sebagai ruang terbuka masyarakat kampung. Istana Kadriyah merupakan saksi sejarah perkembangan pusat pemerintahan Kesultanan Pontianak. Cikal bakal utamanya juga didirikan pertama kali oleh Sultan Syarif Abdurrahman Al-Kadrie sejak tahun 1771. Memasuki ruang singgasana, atau masyarakat umum menyebutnya ruang utama, kini dimanfaatkan sebagai ruang pameran benda-benda bersejarah peninggalan kerajaan. Jika dilihat dari penggunaan ruangnya, istana ini merupakan bangunan rumah tinggal dengan skala yang cukup besar.

Dapat disimpulkan bahwa bangunan Masjid Jami' dimanfaatkan sebagai area ibadah dan wisata religi. Sementara Keraton Kadriyah dimanfaatkan sebagai museum peninggalan benda bersejarah. Kedua bangunan bersejarah yang ada di kawasan penelitian dimanfaatkan sebagai objek wisata religi dan sejarah. Hasil tersebut menunjukan bahwa bangunan cagar budaya yang ada di kawasan memiliki nilai adaptif yang tinggi. Kondisi tersebut sesuai dengan tujuan penelitian, terutama dari aspek nilai budaya di kawasan. Fungsi bangunan tidak hanya dinilai secara deskriptif saja tetapi memiliki nilai eksploratif antara lain nilai historisnya yaitu sebagai saksi dan bukti bahwa kampung tersebut betul adanya sebagai permukiman kesultanan; nilai seni yaitu ditunjukkan dengan fasad dan massa bangunan yang secara arsitektur mencirikan estetika dan kekuasaan Kesultanan Pontianak pada masa itu; nilai pengetahuan yaitu dibuktikan dengan adanya peninggalan-peninggalan sejarah yang bernilai tinggi dan memiliki memori yang dapat dimanfaatkan sebagai sarana pembelajaran generasi mendatang. Karakter kampung sebagai permukiman di kawasan kesultanan menampilkan saksi bisu dari kampung baik tata cara kehidupan dan budaya dari penduduknya. Kepedulian pemerintah dalam memelihara bangunan sejarah sudah tampak di Kampung Beting.

Dari keenam komponen karakter fisik, kondisi yang berada dalam kebertahanan terdapat pada 4 (empat) komponen, yaitu komponen jalur sebagai akses dan penghubung, komponen transportasi air, komponen promenade, dan komponen aset historis yang dikonservasi. Dapat disimpulkan bahwa komponen yang membentuk karakter fisik kampung sebagai permukiman waterfront heritage mayoritas dalam kondisi bertahan. Komponen yang bertahan, terlihat bahwa terfokus pada karakter waterfront dan heritage nya. Komponen fisik waterfront, yaitu ruang terbuka, transportasi air, dan promenade. Komponen transportasi air dan promenade merupakan komponen yang paling mendukung kebertahanan karakter kampung secara fisik sebagai kawasan dengan peruntukan waterfront. Terutama waterfront sebagai ruang rekreasi dan ruang terbuka Kota Pontianak, meskipun komponen ruang terbuka di Kampung Beting belum dapat mendukung kebertahanan karakter sebagai kawasan rekreasi sungai. 
Tabel 2 menunjukkan hasil analisis kebertahanan karakter fisik Kampung Beting secara keseluruhan.

Tabel 2. Hasil analisis kebertahanan karakter fisik Kampung Beting sebagai kawasan permukiman waterfront heritage.

\begin{tabular}{|c|c|c|c|}
\hline \multirow[b]{2}{*}{ Variabel } & \multirow[b]{2}{*}{ Hasil Analisis } & \multicolumn{2}{|c|}{ Nilai Kebertahanan } \\
\hline & & Bertahan & $\begin{array}{c}\text { Tidak } \\
\text { Bertahan }\end{array}$ \\
\hline $\begin{array}{l}\text { Kinerja ruang terbuka } \\
\text { (open space) }\end{array}$ & $\begin{array}{l}\text { Dari } 9 \text { sub komponen, terdapat } 2 \text { (dua) sub yang } \\
\text { mencukupi nilai kinerja adaptif sebagai komponen } \\
\text { pendukung ruang terbuka hijau yaitu komponen } \\
\text { dermaga dan lapangan terbuka hijau. Nilai kinerja } \\
\text { ruang terbuka di kawasan penelitian adalah } 22,2 \% \text {. }\end{array}$ & & $\sqrt{ }$ \\
\hline $\begin{array}{lr}\text { Kinerja jalur sebagai } \\
\text { akses } \\
\text { penghubung }\end{array}$ & $\begin{array}{l}\text { Kinerja jalur jalan sebagai akses dan penghubung di } \\
\text { kawasan penelitian dinilai memenuhi ketiga sub } \\
\text { komponen. }\end{array}$ & $\sqrt{ }$ & \\
\hline $\begin{array}{l}\text { Kinerja transportasi } \\
\text { air di kawasan } \\
\text { penelitian }\end{array}$ & $\begin{array}{l}\text { Kinerja transportasi air di kawasan penelitian bernilai } \\
\text { positif, karena meskipun eksistensi transportasi air } \\
\text { berkurang, namun ketersediaan jumlah dan jenis } \\
\text { kendaraan air masih banyak ditemukan. Ditambah } \\
\text { dengan adanya kelengkapan terminal sampan dan } \\
\text { trayek. }\end{array}$ & $\sqrt{ }$ & \\
\hline Kinerja promenade & $\begin{array}{l}\text { Terdapat } 1 \text { (satu) sub komponen yang tidak } \\
\text { memenuhi kriteria ideal promenade yaitu } \\
\text { ketersediaan area hijau berupa pepohonan di } \\
\text { sepanjang tepian promenade. Nilai adaptif fisik } \\
\text { promenade di kawasan penelitian bernilai sebesar } \\
80 \% \text {. }\end{array}$ & $\sqrt{ }$ & \\
\hline $\begin{array}{l}\text { Kinerja rumah dan } \\
\text { bangunan tepi air }\end{array}$ & $\begin{array}{l}\text { Terdapat } 2 \text { (dua) sub komponen yang memiliki nilai } \\
\text { adaptif yang cukup. Yaitu bangunan yang } \\
\text { mempertahankan tipe bangunan tepi air serta } \\
\text { kelengkapan dan keterjangkauan sarana pendukung } \\
\text { permukiman yaitu pendidikan, perdagangan dan } \\
\text { kesehatan. Sementara dari segi prasarana } \\
\text { permukiman, dapat disimpulkan bahwa kawasan } \\
\text { permukiman belum memiliki jaringan prasarana yang } \\
\text { layak. Nilai adaptif rumah dan bangunan tepi air di } \\
\text { kawasan penelitian memiliki nilai } 33,3 \% \text {. }\end{array}$ & & $\sqrt{ }$ \\
\hline $\begin{array}{lr}\text { Kinerja aset } & \text { historis } \\
\text { kawasan } & \text { yang } \\
\text { dikonservasi } & \end{array}$ & $\begin{array}{l}\text { Kedua indikator yang ada ternyata memenuhi kinerja } \\
\text { aset historis kawasan penelitian. Hingga saat ini, } \\
\text { cagar budaya yang ada di kawasan penelitian } \\
\text { dimanfaatkan sebagai objek wisata religi dan wisata } \\
\text { budaya. }\end{array}$ & $\sqrt{ }$ & \\
\hline
\end{tabular}


Komponen fisik heritage yaitu kinerja aset historis yang dikonservasi, menunjukkan nilai yang positif. Bangunan cagar budaya yang terdapat di kampung hingga saat ini tidak terbengkalai baik dari fungsi bangunan dan fungsi pemanfaatannya. Cagar budaya dimanfaatkan sebagai objek wisata religi dan wisata budaya. Komponen jalur merupakan komponen pendukung fisik. Secara keseluruhan, sebagai kawasan wisata dan permukiman, aksesibilitas menjadi sangat penting sebagai sarana dan prasarana yang mewadahi aktivitas wisatawan dan penduduk kampung.

Komponen yang terancam adalah komponen karakter fisik permukiman, terutama pada sub komponen prasarana pendukung permukiman. Minimnya penyediaan dan pelayanan air bersih dari PDAM, penyediaan sistem sanitasi yang buruk, dan penyediaan dan pelayanan jaringan persampahan yang buruk berdampak terhadap lingkungan fisik permukiman, salah satunya adalah pencemaran sungai, tentu hal tersebut berpengaruh terhadap kebertahanan karakter kawasan dari segi waterfront heritage. Kekumuhan menimbulkan ketidaknyamanan bagi wisatawan kemudian stigma negatif kampung pun semakin terasa.

\section{Kesimpulan}

Kampung Beting merupakan kawasan yang ditujukan sebagai kawasan urban heritage Kota Pontianak. Pembangunan kawasan kampung sudah mulai dilakukan sejak tahun 2017 hingga saat ini, mulai dari pembangunan promenade, jetty sampan, hingga revitalisasi bangunan sejarah. Pembangunan tersebut ditujukan untuk mengarahkan kampung sebagai daerah wisata budaya yang secara geografis berada di tepian Sungai Kapuas. Pembangunan tersebut secara teori kebertahanan juga merujuk kepada upaya pembentukan kembali karakter dan identitas kawasan sebagai permukiman waterfront heritage. Beberapa hal yang menjadi ancaman terhadap kebertahanan karakter pada kawasan diantaranya kondisi perumahan yang tidak layak, minimnya sarana dan prasarana pendukung sehingga mempengaruhi penurunan karakter kawasan yang ideal sebagai kawasan permukiman waterfront heritage.

Berdasarkan analisis data kualitatif model Miles and Huberman [9] didapatkan hasil bahwa secara umum kebertahanan karakter Kampung Beting dari segi fisik berada dalam kondisi kebertahanan cukup tinggi. Kebertahanan fisik yang tampak terutama dari aspek waterfront dan heritagenya. Kebertahanan kawasan kampung sebagai kawasan waterfront dibuktikan dengan hasil kinerja promenade, ruang terbuka, dan transportasi air yang tinggi. Kebertahanan kawasan kampung sebagai kawasan heritage dibuktikan dengan hasil kinerja aset historis kawasan yang dikonservasi. Kinerja transportasi air yang tinggi dibuktikan dengan kondisi eksistensi transportasi air yang masih mudah ditemukan dan masih dimanfaatkan sebagai sarana rekreasi ditambah dengan prasarana penunjang yaitu terminal sampan dan trayek sungai. Kinerja jalur yang baik juga berpengaruh terhadap kemudahan akses kawasan baik untuk pengunjung dan penduduk kampung.

Karakter pembentuk identitas kawasan kampung sangat diperkuat oleh keberadaan fisik bangunan rumah dan keberadaan promenade serta fasilitas penunjang aktivitas air untuk kegiatan pariwisata. Akan tetapi, nilai kebertahanan rendah ada pada kinerja rumah dan bangunan tepi air terutama dari segi penyediaan dan pelayanan jaringan prasarana 
pendukung permukiman. Dikarenakan kondisi permukiman yang padat dan persil bangunan yang tidak terkontrol, letak bangunan yang berada langsung di atas sungai menyulitkan pengadaan jaringan air bersih dan sanitasi terutama sistem drainase dan tangki septic. Dari kondisi di atas, direkomendasikan adanya pengoptimalan fungsi permukiman baik dari segi kemampuan bangunan itu sendiri dan peningkatan penyediaan dan pelayanan prasarana pendukung permukiman. Selain itu, juga dibutuhkan adanya penggalakan konservasi lingkungan sekitar sungai dengan tujuan untuk menciptakan keseimbangan lingkungan sehingga dapat menciptakan kawasan permukiman sekaligus kawasan wisata yang nyaman dan berkelanjutan tanpa adanya kekumuhan dan pencemaran sungai yang semakin parah.

\section{Referensi}

[1] Budhisantoso S, Bale D, Suprapti, Suhardi. Analisis Pola Pemukiman di Lingkungan Perairan di Indonesia. Jakarta: Departemen Pendidikan dan Kebudayaan, Direktorat Jenderal Kebudayaan, Direktorat Sejarah dan Nilai Tradisional; 1994.

[2] Sabini FW. Kementerian PUPR Tata 11 Kampung Nelayan. Koran Jakarta 2019.

[3] Cumming GS, Barnes G, Perz S, Schmink M, Sieving KE, Southworth J, et al. An Exploratory Framework for The Empirical Measurement of Resilience. Ecosystems 2005;8:975-87. https://doi.org/10.1007/s10021-005-0129-z.

[4] Puastika AR, Yuliastuti N. Kebertahanan Permukiman Sebagai Potensi Keberlanjutan di Kelurahan Purwosari Semarang. J Tek PWK 2012;1:21-8.

[5] Longstaff PH, Armstrong NJ, Perrin K, Parker WM, Hidek MA. Building Resilient Communities: A Preliminary Framework for Assessment. Homel Secur Aff 2010;6:123.

[6] Sari IK. Perubahan Karakter Arsitektur Permukiman Kampung Beting Kota Pontianak Kalimantan Barat. J Arsit Langkau Betang 2014;1:62-75. https://doi.org/10.26418/lantang.v1i1.18809.

[7] Khaliesh H, Widiastuti I, Budi BS. Karakteristik Permukiman Tepi Sungai Kampung Beting di Pontianak: dari Rumah Lanting ke Rumah Tiang. Pros. Temu IIm. IPBLBI 2012, 2012, p. 69-72.

[8] Sugiyono. Metode Penelitian Kombinasi Mixed Methods. Bandung: Alfabeta; 2014.

[9] Emzir. Metodologi Penelitian Kualitatif: Analisis Data. Jakarta: Rajawali Pers; 2010.

[10] Tangkuman DJ, Tondobala L. Arsitektur Tepi Air. Media Matrasain 2011;8:40-54.

[11] Khaliesh H, Widiastuti I, Budi BS. Karakteristik Permukiman Tepian Sungai Kampung Beting di Pontianak. Temu IIm. IPLBI, Bandung: Temu Ilmiah Ikatan Peneliti Lingkungan Binaan Indonesia; 2012, p. 69-72. 